\title{
Cystatin C biosensors for diagnosis of kidney failure - A literature review
}

\author{
Erika Ketlem Gomes Trindade, Rosa Fireman Dutra * \\ Biomedical Engineering Laboratory, Department of Biomedical Engineering. Federal \\ University of Pernambuco, Av. Prof. Moraes Rego, 1235, CEP 50610-970 - Recife, Brazil. \\ *Corresponding author: \\ Prof. Rosa Fireman Dutra \\ E-mail address: rosa.dutra@ufpe.br \\ Phone/fax: +55 8121267325 .
}

\begin{abstract}
Kidney diseases are a major global health threat and the development of new and improved detection methods for early diagnostic is imperative. Biosensors are devices capable of delivering rapid and specific results, allied to the possibility of miniaturization and point-ofcare diagnostics. Different transducing methods are presented and different nanomaterials are involved to produce optical and electrochemical approaches with low detection limits and fast responses. This paper reviews the current state-of-the-art in biosensor researches regarding efficient, specific and rapid detection of Cystatin $\mathrm{C}(\mathrm{Cys})$, an early kidney failure biomarker. A comprehensive literature search was performed, which included primary research studies on biosensors for Cystatin $\mathrm{C}$ detection. Although there have been great developments in the area, the biggest problem is the miniaturization and the ability to accomplish readings directly in blood or serum. This is a concern approached by some researchers in the biosensor field.
\end{abstract}


Cystatin $\mathrm{C}$ is an effective biomarker for early diagnostic of kidney failure. The current available literature shows a trend towards the development of methods capable of simple detection with few steps to obtain readings. This has the potential to enhance outcomes for patients in dialysis and intensive care units.

Keywords: Kidney diseases; Diagnostics; Biosensors; Nanomaterials; Cystatin C.

\section{Introduction}

Studies have shown that the incidence of Acute Kidney Injury (AKI) has been increasing in recent decades and can most likely result in permanent kidney damage [1]. The incidence of AKI has been reported to be up to $20 \%$ in the USA and very similar in other countries $[2,3]$. It is estimated that AKI occurs in the range of $20-200$ per million of population, $7-18 \%$ of hospitalized patients and approximately $50 \%$ of patients in the Intensive Care Unit (ICU) $[3,4]$. AKI has been associated with high morbidity and mortality, killing about 2 million people in the world and hospital mortality rates in patients hospitalized with AKI are very high among patients requiring dialysis $[3,5,6]$. Since AKI is an independent risk factor for Chronic Kidney Disease (CKD), End Stage Renal Disease (ESRD), heart disease and death, it is a significant public health concern worldwide [3,5,7].

Currently, $\mathrm{CKD}$ has a high global prevalence, estimated at 11 to $13 \%$, with a higher prevalence of the final stages (stages 3 to 5), and it is a significant cause of morbimortality $[8,9]$. Low and middle class countries have experienced an alarming increase in the number of CKD in the last 20 years, with a significant association with diabetes mellitus, hypertension, cardiovascular diseases, high body mass index, among others $[10,11]$. Accordingly, there was an annual increase in dialysis program expenses worldwide, ranging from $6 \%$ to $12 \%$ and continuing to grow [12]. In the US, more than 400,000 americans have end-stage renal disease and more than 300,000 of these patients require dialysis. Mortality rates remain above $20 \% /$ year with the use of dialysis, and the annual medical costs directly related to end-stage renal disease is almost US\$ 23 billion [13]. In Brazil, between 2000 and 2012, the incidence increased by $20 \%$, meaning $1.8 \%$ /year in all regions of the country and particularly in older age groups. As observed, incidence and prevalence of CKD in patients who received dialysis 
treatment increased significantly [12]. In this sense, there is a great interest in the development of analytical methods and new strategies for the early detection of kidney failure.

\section{Methodology}

This review has aimed to synthesize the literature encompassing biosensor development for cystatin $\mathrm{C}$ detection, which allows the summary of the known literature regarding the research in question into a succinct model that enables new understandings to emerge. This is not a mature topic, but a subject matter that is in constant update due to constant research and improvement on the field. The objective of this paper is to condense current state-of-the-art research on biosensors in order to allow better understanding and further improvement on the field.

\section{Discussion}

\subsection{CURRENT DIAGNOSTIC OF KIDNEY FAILURE}

The knowledge of Glomerular Filtration Rate (GFR) is essential for detection and monitoring of decreased kidney function [14] . A decreased kidney function is a predictor of hospitalization, cognitive dysfunction and bad quality of life [8]. There is an inverse relationship between risk of CKD and GFR that is independent of age, gender, and other risk factors. GFR measurement performed through external filtration markers is both uncomfortable and impractical [15], and it has long been estimated by equations using serum creatinine concentrations [16]. However, creatinine is influenced not only by GFR, but also by other factors, including muscle mass, age, gender, drugs, catabolic state, amount of ingested meat and tubular secretion $[17,18]$.

The search for an alternative marker for early detection of kidney diseases led to serum cystatin $\mathrm{C}(\mathrm{Cys} C)$. CysC and creatinine are products of very different metabolic pathways and are measured by independent assays [19] . Nevertheless, CysC is less sensitive to physiological or pathological changes than creatinine [20]. Recent studies have indicated that serum CysC concentration is a better marker in cases of mild renal failure, being more stable in the estimation of GFR and more accurate for the risk prediction of CKD [21-25]. 
CysC is a low molecular weight $(13 \mathrm{kDa})$ glycosylated protein of the class of cysteine protease inhibitors. It is produced at a constant rate by nucleated cells and is present in biological fluids. It was suggested as an alternative marker for GFR in 1979, and the first automated procedure for cystatin C analysis was introduced in 1994 [17,26] . CysC is freely filtered by the glomeruli without tubular reabsorption or secretion [20], and its serum concentration is independent of diet, muscle mass and body weight, and there are no significant differences between the reference values for females and males. Due to this, CysC is considered an early marker of GFR-related renal dysfunction [26,27]. In addition, CysC is a marker that has been increasingly used in the monitoring of patients on dialysis (haemodialysis, peritoneal dialysis, etc.) [18,28]. Thus, this marker can indicate early signs of kidney disease, allowing an early diagnosis and reduction of cases of $\mathrm{CKD}$, as well as the monitoring of this condition in patients using dialysis.

The detection of cystatin $\mathrm{C}$ can be done directly, through the binding of antigen-antibody, or indirectly, by observing the activity of papain or the formation of a sandwich immunocomplex (Fig. 1).

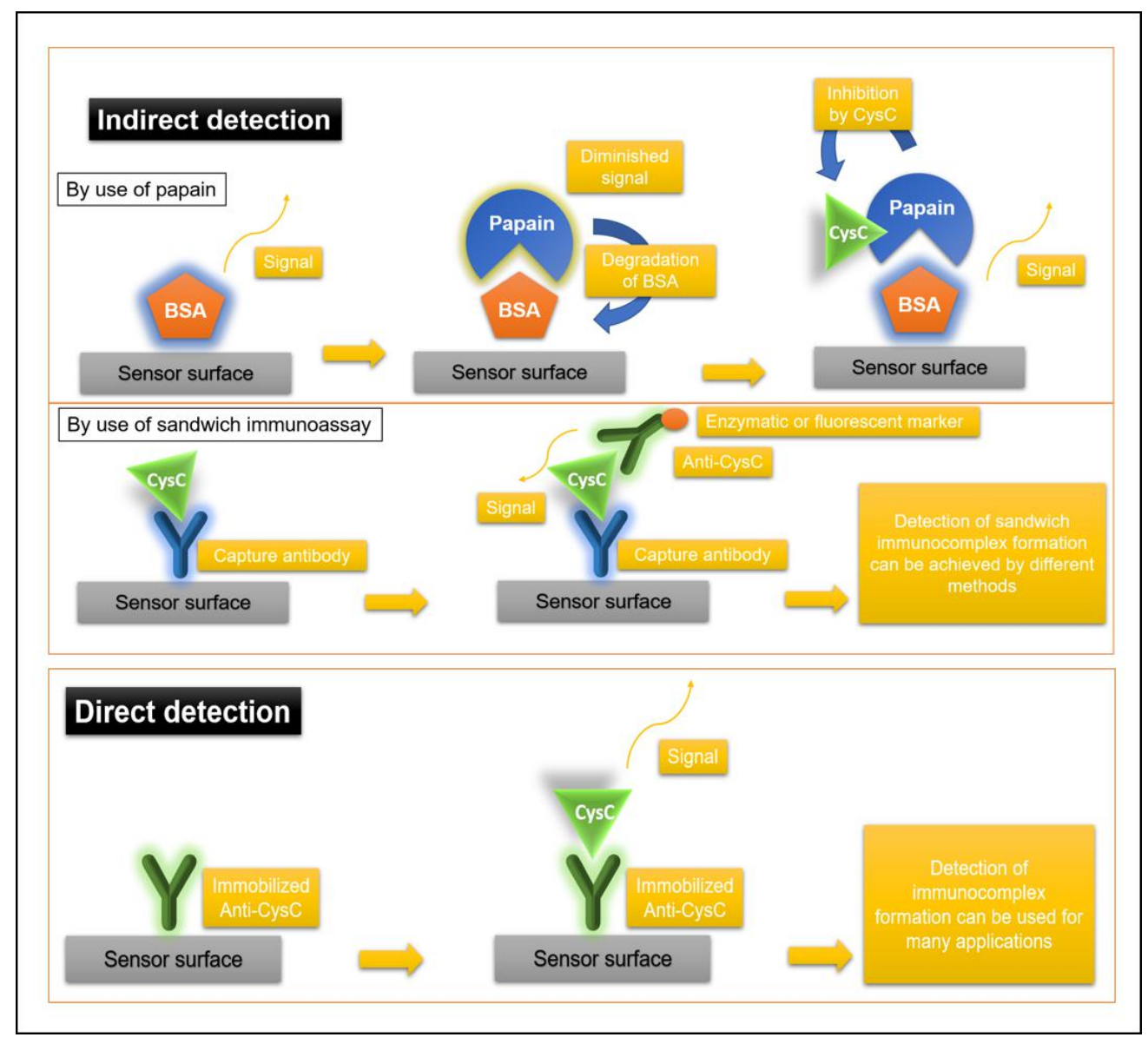

Figure 1. Indirect and direct strategies for Cystatin C detection. 
Papain is a $23 \mathrm{kDa}$ protein belonging to the cysteine protease family [29]. As CysC is a cysteine protease inhibitor, its detection is done indirectly by observing the decrease in papain activity [30,31]. Indirect detection can also be achieved by the detection of a sandwich immunocomplex formation, using an antibody marked with fluorescent or enzymatic molecules, or elements of bioaffinity such as the biotin-streptavidin complex coupled with other markers [32]. The direct detection of cystatin $\mathrm{C}$, however, is done through the binding of cystatin $\mathrm{C}$ to the anti-cystatin $\mathrm{C}$ antibody. Thus far several analytical strategies have been used for the detection of serum CysC, such as Enzyme-Linked immunosorbent assay (ELISA) [33] , particle-enhanced turbidimetric immunoassay (PETIA) and particle-enhanced nephelometric immunoassay (PENIA) [20,34]. However, these are time-consuming methods and require specialized personnel to operate. Due to this and to the great interest in the rapid detection of $\mathrm{CysC}$, biosensors involving the two ways of detection were found in the literature.

\subsection{CONCEPT OF BIO AND IMMUNOSENSORS}

Biosensors are analytical devices that use biological components as recognition elements for detection of target analytes. Such devices combine a detection system (biological receptor with biorecognition capabilities), transduction (which has the ability to translate the biological binding signal into an electric signal) and amplification of the biorecognition signal generated (which allows the signal visualization) (Fig. 2) [35]. There are several types of biosensors, classified according to the transducer (optical, electrochemical, piezoelectric, etc.), or according to the biomolecule immobilized on the detection surface (bioreceptor) (proteins, DNA, antibodies, among others). In recent years, the number of researches on biosensors has been increasing dramatically. This area has been growing rapidly in recent decades, with the development of new nanomaterials and methods of surface functionalization, expanding the possibilities in several areas [36]. 


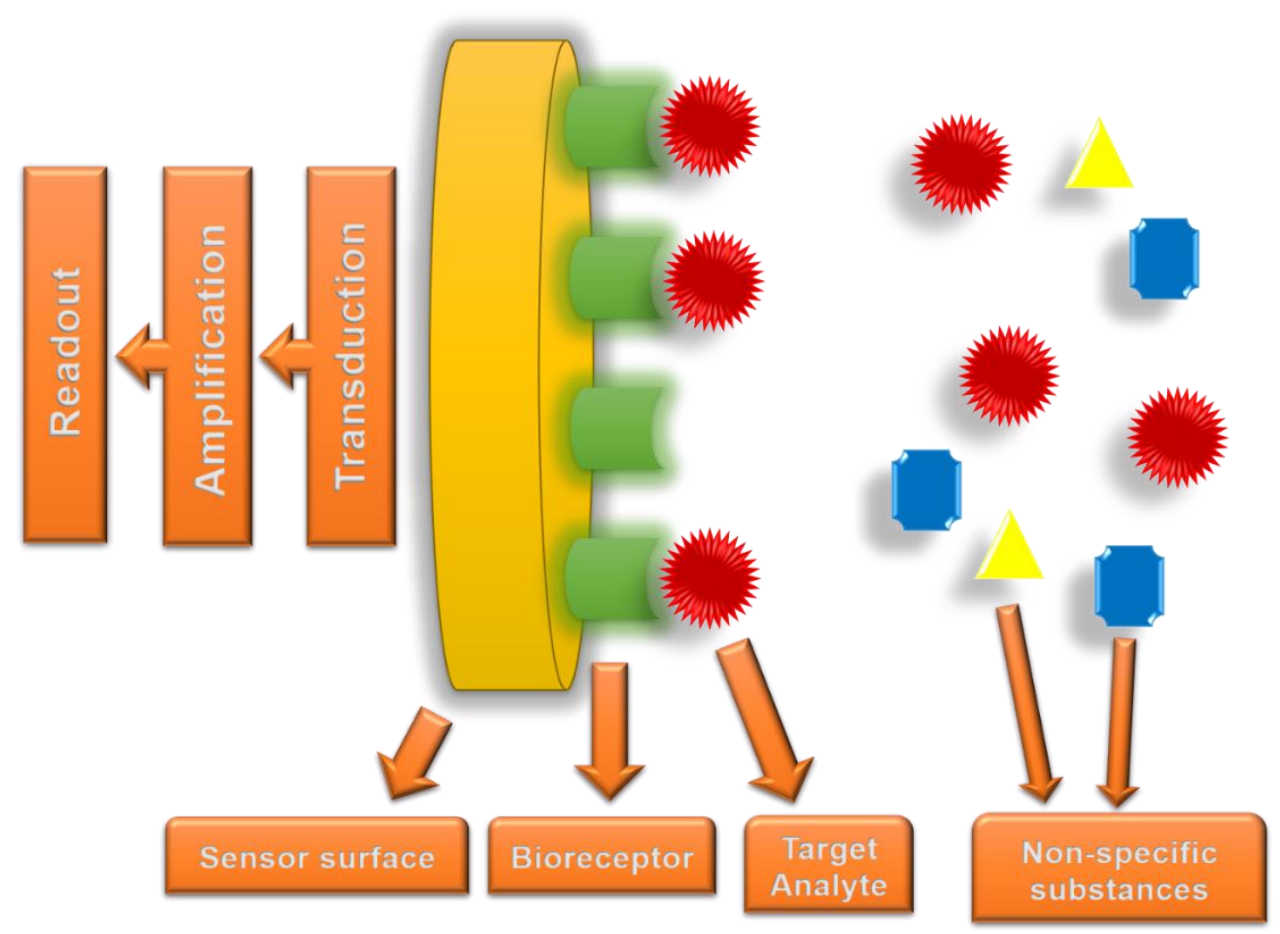

Figure 2. Schematic diagram of biosensors principle.

The biosensors based on antigen-antibody, lectin-carbohydrate or DNA interactions are commonly classified as affinity sensors [37]. When the proteins used as bioreceptors are antibodies or antigens, they can be further categorized as immunosensors [38,39]. Moreover, when the biorecognition element is DNA, these biosensors are usually called genosensors [40] and enzymatic sensors are those that use the activity of enzymes as detection elements [41].

\subsection{BIO AND IMMUNOSENSORS FOR CYSTATIN C}

Most biosensors developed in research today are based on immunological reactions or DNA hybridization, and these tests allow fast results with great sensitivity [42]. For the detection of serum cystatin $\mathrm{C}$, biosensors, immunoassays and immunosensors were developed involving many detection strategies and methods (Table 1). Papain was commonly used for indirect biorecognition of $\mathrm{CysC}$, which is generally based on the diminished activity of papain in the presence of the inhibitor. Lin et al. (2013), for example, performed an optical detection using a method for indirect Cystatin C detection by BSA-stabilized Au nanoclusters (Au NCs) as fluorescent probe [31]. Au nanoclusters are fluorescent gold nanoparticles which have been widely used for biosensor applications [43]. The fluorescence emitted by the BSA-Au nanoclusters was reduced due to the degradation of BSA by papain. When in the presence of $\mathrm{CysC}$, the degradation stopped and fluorescence was restored. Another example is the work of Gorodkiewicz and Luszczyn (2011), which immobilized papain onto a gold surface 
functionalized with cysteamine, using Surface Plasmon Resonance Imaging (SPRI) for the detection of CysC [29]. Additionally, there is the work of Tao et al. (2016), which used nearinfrared (NIR) light emitting PbS@BSA quantum dots (QDs) to detect CysC using papain to hydrolyse BSA [27]. Quantum dots are semiconductor nanocrystals that generally have dimensions in the range of 2-6nm [44], with a wide range of light emitting frequencies. The PbS@BSA QDs NIR fluorescence intensity decreased with the degradation of BSA and was then restored by the inhibition action of CysC. Another optical method used in the detection of CysC was LSPR (Localized Surface Plasmon Resonance). Puttaswamy et al., (2020) used LSPR as the detection method for a microneedle array functionalized with anti-CysC for analysis in filtrated whole blood [45] Lesnak et al., (2021), on the other hand, used SPRi (Surface Plasmon Resonance imaging) for detection of anti-CysC in urine [46]. However, these optical detection systems are very hard to miniaturize, which makes it difficult for "point-of-care" detection. Papain was also used in an electrochemical biosensor using a carbon nanotube-immobilized screen-printed electrode by Desai et al., (2018) [30] . Carbon nanotubes can be described as hollow cylindrical tubes of graphene sheets with high aspect ratios (length/diameter) [36], providing efficient electron transfer and high surface area [30]. Nevertheless, these papain-based detection methods have the disadvantage of being limited for using only in urine, since papain is a serine protease that detects enzymatic activity [47]. 
Table 1. Summary of the works presented in this review, categorized by detection methods for CysC, manner of detection, the biomolecule used, range of detection and detection limits.

\begin{tabular}{|c|c|c|c|c|}
\hline Detection method & $\begin{array}{c}\text { Manner of } \\
\text { detection }\end{array}$ & Biomolecule & Range of detection and LOD & Reference \\
\hline Electrochemiluminescence (Optic) & Indirect & $\begin{array}{c}\text { Antibody-DNA } \\
\text { conjugates }\end{array}$ & $\mathrm{pg} / \mathrm{mL}-100 \mathrm{ng} / \mathrm{mL}(0.483 \mathrm{pg} / \mathrm{mL})$ & Zhao et al., (2018) [49] \\
\hline Localized Surface Plasmon Resonance (Optic) & Direct & Anti-CysC & $---(0.01 \mu \mathrm{g} / \mathrm{mL})$ & $\begin{array}{l}\text { Puttaswamy et al., } \\
\quad(2020)[45]\end{array}$ \\
\hline Surface Plasmon Resonance imaging (Optic) & Direct & Anti-CysC & $---(0.1 \mathrm{mg} / \mathrm{L})$ & $\begin{array}{l}\text { Lesnak et al., (2021) } \\
{[46]}\end{array}$ \\
\hline $\begin{array}{c}\text { Cyclic Voltammetry/Electrochemical Impedance } \\
\text { Spectroscopy (Electrochemical) }\end{array}$ & Direct & Anti-CysC & $\begin{array}{l}0-300 \mathrm{ng} / \mathrm{mL} \\
(24 \mathrm{ng} / \mathrm{mL})\end{array}$ & $\begin{array}{l}\text { Ferreira et al., (2020) } \\
\text { [54] }\end{array}$ \\
\hline $\begin{array}{c}\text { Cyclic Voltammetry/Square Wave Voltammetry } \\
\text { (Electrochemical) }\end{array}$ & Direct & Anti-CysC & $\begin{array}{l}0.1-1000 \mathrm{ng} / \mathrm{mL} \\
(0.03 \mathrm{ng} / \mathrm{mL})\end{array}$ & $\begin{array}{l}\text { Trindade and Dutra, } \\
\text { (2019) [47] }\end{array}$ \\
\hline Fluorescence Resonance Energy Transfer (Optic) & Indirect & Aptamers & --- $(0.16 \mathrm{ng} / \mathrm{mL})$ & Wang et al., (2021) [51] \\
\hline Linear sweep voltammetry (Electrochemical) & Indirect & $\begin{array}{l}\text { Biotinylated anti-CysC } \\
\text { (sandwich immunoassay) }\end{array}$ & $\begin{array}{l}10-100 \mathrm{ng} / \mathrm{mL} \\
(6.0 \mathrm{ng} / \mathrm{ml})\end{array}$ & Lopes et al., (2019) [50] \\
\hline Photoelectrochemical & Direct & CysC-specific nanobodies & $0.72 \mathrm{pM}-3.6 \mathrm{nM}(0.14 \mathrm{pM})$ & Mi et al., (2016) [22] \\
\hline Differential pulse voltammetry (Electrochemical) & Indirect & DNA strands & $1 \mathrm{pg} / \mathrm{mL}-30 \mathrm{ng} / \mathrm{mL}(3 \mathrm{fg} / \mathrm{mL})$ & Yang et al., (2016) [48] \\
\hline $\begin{array}{c}\text { Cyclic Voltammetry/Differential pulse voltammetry } \\
\text { (Electrochemical) }\end{array}$ & Direct & $\begin{array}{l}\text { Molecularly imprinted } \\
\text { polymers (MIPs) }\end{array}$ & $\begin{array}{l}0.5-20 \mathrm{ng} / \mathrm{mL} \\
(0.5 \mathrm{ng} / \mathrm{mL}) \\
\end{array}$ & $\begin{array}{l}\text { Gomes et al., (2021) } \\
\text { [53] }\end{array}$ \\
\hline Surface Plasmon Resonance (Optical) & Indirect & Papain & $\begin{array}{l}0-0.6 \mu \mathrm{g} / \mathrm{mL} \\
(0.09 \mu \mathrm{g} / \mathrm{mL})\end{array}$ & $\begin{array}{c}\text { Gorodkiewicz and } \\
\text { Luszczyn, (2011) [29] }\end{array}$ \\
\hline Fluorescence (Optical) & Indirect & Papain & $\begin{array}{c}25 \mathrm{ng} / \mathrm{mL}-2 \mu \mathrm{g} / \mathrm{mL} \\
(4 \mathrm{ng} / \mathrm{mL})\end{array}$ & Lin et al., (2013) [31] \\
\hline $\begin{array}{c}\text { Cyclic voltammetry/differential pulse voltammetry } \\
\text { (Electrochemical) }\end{array}$ & Indirect & Papain & $\begin{array}{c}0.6-6.6 \mathrm{ng} / \mu \mathrm{L} \\
(---)\end{array}$ & Desai et al., (2018) [30] \\
\hline Near-infrared Quantum dots (Optical) & Indirect & Papain and BSA & $0.5-4 \mu \mathrm{g} / \mathrm{mL}(---)$ & Tao et al., (2016) [27] \\
\hline $\begin{array}{c}\text { Surface-Enhanced Raman Spectroscopy } \\
\text { (optical)/Differential pulse voltammetry } \\
\text { (Electrochemical) }\end{array}$ & Direct & $\begin{array}{l}\text { Thiolated antibody } \\
\text { fragments }\end{array}$ & $\begin{array}{c}1 \times 10^{-7} \mathrm{M}-1 \mathrm{pM}(1 \mathrm{pM})(\mathrm{SERS}) \\
6.25 \times 10^{-8} \mathrm{M}-1 \mu \mathrm{M}(62.5 \mathrm{nM}) \\
(\mathrm{DPV})\end{array}$ & $\begin{array}{l}\text { Hassanain et al., (2018) } \\
\text { [52] }\end{array}$ \\
\hline
\end{tabular}


Sensors using DNA hybridization were also developed. Yang et al., (2016a) performed the detection by displacement of the DNA strand induced by an immunoreaction and cyclic enzymatic amplification of the T7 Exonuclease protein (T7 Exo) [48]. In the presence of $\mathrm{CysC}$, a sandwich immunoreaction would induce proximity hybridization between two DNA strands and the signal was read due to electron mediator thionine in this electrochemical biosensor. The detection method obtained, however, relies on many steps to achieve CysC detection and the use of external markers to achieve a measurable signal. Zhao et al., (2018), on the other hand, used a graphene-rubrene (an organic semiconductor) composite in the development of an electrochemiluminescence sensor [49]. Antibody-DNA conjugates were used, and the sandwich immunocomplex formation was used to displace a ferrocene-labelled blocker strand, decreasing the signal when there was an increase in CysC concentration. This indirect detection by DNA developed was less tiresome than the latter, although it has the same disadvantages of other optical detection techniques.

Some studies accomplished the detection of $\mathrm{CysC}$ was by using immunoassays. Lopes et al., (2019) used screen-printed electrodes in order to develop a sandwich-type electrochemical immunosensor for cystatin C [32]. Gold nanoparticles were electrodeposited onto the electrode and used to immobilize the capture antibody, which was then coupled with CysC. Detection was mediated by a biotinylated anti-CysC using a tracer enzyme marked with streptavidin. Wang et al., (2021) also used an external marker for detection of CysC, developing a fluorophore-labelled aptamer-based platform for optical FRET analysis [51] . However, these "point-of-care" detection systems relying on enzymes tend to lose activity over time. Furthermore, the usual electrochemical sensor has the disadvantage of needing external redox probes to achieve readings. The work of Hassanain et al., (2018), on the other hand, used direct detection by anti-CysC fragments mixed with bond breaker TCEP to reduce disulphide bonds and produce thiolated antibody fragments, and the mixture was loaded into a gold coated silicon nanopillar in order to obtain the stable S-Au bond [52]. Surface Enhanced Raman Spectroscopy (SERS) and electrochemistry were used for detection of CysC. The detection by SERS showed an excellent detection range; however, these optical methods are susceptible to the disadvantages mentioned before. Another work to use antibody fragments was that of Mi et al., (2016). A distinct type of antibody fragment derived from the variable heavy chain known as nanobodies, considered the smallest antigen-binding fragment, was used in a photoelectrochemical immunosensor based on titanium nanotubes. The detection was accomplished by photocurrent response under radiation with visible light using a $150 \mathrm{~W}$ 
Xe lamp. Gomes et al., (2021), however, developed plastic antibodies based on molecularly imprinted polymers (MIPs) in order to build an electrochemical detection surface using $\mathrm{CV}$ and DVP to allow measurements in serum [53]. Other works, however, opted for using the whole anti-CysC monoclonal antibody to accomplish readings. That includes the work of Ferreira et al., (2020), which used Interdigitaded Electrodes (IDEs) as platforms for immobilization of the antibodies, accomplishing electrochemical readings using CV and EIS (Electrochemical Impedance Spectroscopy) in human serum [54]. Trindade et al., (2019) used the anti-CysC immobilized in a redox active surface composed of graphene-ferrocene nanocomposite and polyethyleneimine [47]. Graphene is a two-dimensional sheet, composed by carbon atoms that are densely packed in a regular sp2-bonded atomic scale as a hexagonal pattern and is the base construction block for other carbon allotropes such as fullerene, carbon nanotubes, graphite, nanoribbons, and others [36] ; ferrocene is a redox mediator widely known and vastly used [47]. Electrochemical CysC readings were accomplished without external redox probes, in an attempt to circumvent usual "point-of-care" detection limitations.

\section{Conclusion}

Rapid and direct detection of $\mathrm{CysC}$ remains a concern for researchers worldwide. Seeing that metabolic diseases have been growing with the aging of the population and these diseases frequently lead to kidney damage, the preventive and early detection of kidney failure is a great concern. Thus, it is foreseeable that many more detection methods and strategies will be developed in the near future for the screening and monitoring of kidney failure. There has been some growth in the development of biosensors for CysC detection in the recent years, but there is still great room for improvement. The biosensor field has been changing, and the current trend tends towards the development of better electrochemical immunosensors that do not rely on redox probes to achieve readings, in order to avoid "point-of-care" drawbacks and allow the diagnostic at the bedside.

\section{ACKNOWLEDGEMENTS}

This research was supported by CNPq Brazilian agencies under grants number 440605/2016-4, 471065/2014-5 and 407905/2013-8. E.K.G. Trindade thanks FACEPE and CAPES for her scholarship. CAPES - Brazil Code 001, financed this study in part. 


\section{REFERENCES}

[1] Coca SG, Singanamala S, Parikh CR. Chronic kidney disease after acute kidney injury: A systematic review and meta-analysis. Kidney International. 2012;81(5):442-8.

[2] Gharaibeh KA, Hamadah AM, El-Zoghby ZM, Lieske JC, Larson TS, Leung N. Cystatin C Predicts Renal Recovery Earlier Than Creatinine Among Patients With Acute Kidney Injury. Kidney International Reports. 2018;3(2):337-42.

[3] Hoste EAJ, Bagshaw SM, Bellomo R, Cely CM, Colman R, Cruz DN, et al. Epidemiology of acute kidney injury in critically ill patients: the multinational AKI-EPI study. Intensive Care Medicine. 2015 Aug;41(8):1411-23.

[4] Chawla LS, Bellomo R, Bihorac A, Goldstein SL, Siew ED, Bagshaw SM, et al. Acute kidney disease and renal recovery: Consensus report of the Acute Disease Quality Initiative (ADQI) 16 Workgroup. Nature Reviews Nephrology. 2017;13(4):241-57.

[5] Chawla LS, Eggers PW, Star RA, Kimmel PL. Acute Kidney Injury and Chronic Kidney Disease as Interconnected Syndromes. New England Journal of Medicine. 2014;371(1):58-66.

[6] Chawla LS, Bellomo R, Bihorac A, Goldstein SL, Siew ED, Bagshaw SM, et al. Acute kidney disease and renal recovery: Consensus report of the Acute Disease Quality Initiative (ADQI) 16 Workgroup. Nature Reviews Nephrology. 2017;13(4):241-57.

[7] Webster AC, Nagler E V, Morton RL, Masson P. Chronic Kidney Disease. The Lancet. 2017 Mar;389(10075):1238-52.

[8] Hill NR, Fatoba ST, Oke JL, Hirst JA, Callaghan AO, Lasserson DS, et al. Global Prevalence of Chronic Kidney Disease - A Systematic Review and Meta-Analysis. PLoS ONE. 2016;1-18.

[9] Gifford FJ, Gifford RM, Eddleston M, Dhaun N. Endemic Nephropathy Around the World. Kidney International Reports. 2017;2(2):282-92.

[10] Grams ME, Juraschek SP, Selvin E, Foster MC, Inker LA, Eckfeldt JH, et al. Trends in the prevalence of reduced GFR in the United States: A comparison of creatinine- and cystatin c-based estimates. American Journal of Kidney Diseases. 2013;62(2):253-60. 
[11] de Moura L, Prestes IV, Duncan BB, Thome FS, Schmidt MI. Dialysis for end stage renal disease financed through the Brazilian National Health System, 2000 to 2012. BMC nephrology. 2014;15:111.

[12] de Moura L, Prestes IV, Duncan BB, Thome FS, Schmidt MI. Dialysis for end stage renal disease financed through the Brazilian National Health System, 2000 to 2012. BMC nephrology. 2014;15:111.

[13] Go AS, Chertow GM, Fan D, McCulloch CE, Hsu C. Chronic kidney disease and the risks of death, cardiovascular events, and hospitalization. The New England journal of medicine. 2015;351(13):1296-305.

[14] Grubb A, Horio M, Hansson LO, Björk J, Nyman U, Flodin M, et al. Generation of a new cystatin C-based estimating equation for glomerular filtration rate by use of 7 assays standardized to the international calibrator. Clinical Chemistry. 2014;60(7):974-86.

[15] Jha V, Garcia-Garcia G, Iseki K, Li Z, Naicker S, Plattner B, et al. Chronic kidney disease: Global dimension and perspectives. The Lancet. 2013;382(9888):260-72.

[16] Khorgami Z, Abdollahi A, Soleimani S, Ahamadi F, Mahdavi-Mazdeh M. Relationship between serum cystatin $\mathrm{C}$ and creatinine or dialysis adequacy in patients on chronic maintenance hemodialysis. Nephro-urology monthly. 2013;5(2):733-5.

[17] Grubb A, Horio M, Hansson LO, Björk J, Nyman U, Flodin M, et al. Generation of a new cystatin C-based estimating equation for glomerular filtration rate by use of 7 assays standardized to the international calibrator. Clinical Chemistry. 2014;60(7):974-86.

[18] Khorgami Z, Abdollahi A, Soleimani S, Ahamadi F, Mahdavi-Mazdeh M. Relationship between serum cystatin $\mathrm{C}$ and creatinine or dialysis adequacy in patients on chronic maintenance hemodialysis. Nephro-urology monthly. 2013;5(2):733-5.

[19] Grams ME, Juraschek SP, Selvin E, Foster MC, Inker LA, Eckfeldt JH, et al. Trends in the prevalence of reduced GFR in the United States: A comparison of creatinine- and cystatin c-based estimates. American Journal of Kidney Diseases. 2013;62(2):253-60.

[20] Fonseca I, Reguengo H, Oliveira JC, Martins LS, Malheiro J, Almeida M, et al. A triplebiomarker approach for the detection of delayed graft function after kidney transplantation using serum creatinine, cystatin $\mathrm{C}$, and malondialdehyde. Clinical Biochemistry. 2015;48(16-17):1033-8. 
[21] Fox JA, Dudley AG, Bates C, Cannon Jr. GM. Cystatin C as a marker of early renal insufficiency in children with congenital neuropathic bladder. The Journal of urology. 2014;191(5 Suppl):1602-7.

[22] Mi L, Wang P, Yan J, Qian J, Lu J, Yu J, et al. A novel photoelectrochemical immunosensor by integration of nanobody and $\mathrm{TiO} 2$ nanotubes for sensitive detection of serum cystatin C. Analytica Chimica Acta. 2016;902:107-14.

[23] Ravn B, Prowle JR, Mårtensson J, Martling C-R, Bell M. Superiority of Serum Cystatin C Over Creatinine in Prediction of Long-Term Prognosis at Discharge From ICU. Critical Care Medicine. 2017;1(7):1.

[24] Shlipak MG, Matsushita K, Ärnlöv J, Inker LA, Katz R, Polkinghorne KR, et al. Cystatin $\mathrm{C}$ versus creatinine in determining risk based on kidney function. The New England journal of medicine. 2013;369(10):932-43.

[25] Shlipak MG, Mattes MD, Peralta CA. Update on cystatin C: Incorporation into clinical practice. American Journal of Kidney Diseases. 2013;62(3):595-603.

[26] Lau L, Al-Ismaili Z, Harel-Sterling M, Pizzi M, Caldwell JS, Piccioni M, et al. Serum cystatin $\mathrm{C}$ for acute kidney injury evaluation in children treated with aminoglycosides. Pediatric Nephrology. 2017;1-9.

[27] Tao J, Zhao P, Zeng Q. The determination of cystatin C in serum based on label-free and near-infrared light emitted PbS@BSA QDs. Journal of Materials Chemistry B. 2016;4(24):4258-62.

[28] Hoek FJ, Korevaar JC, Dekker FW, Boeschoten EW, Krediet RT. Estimation of residual glomerular filtration rate in dialysis patients from the plasma cystatin C level. Nephrology Dialysis Transplantation. 2007;22(6):1633-8.

[29] Gorodkiewicz E, Luszczyn J. Surface Plasmon Resonance Imaging (SPRI) Sensor for Cystatin Determination Based on Immobilized Papain. Protein and Peptide Letters. 2011;18(1):23-9.

[30] Desai D, Kumar A, Bose D, Datta M. Ultrasensitive sensor for detection of early stage chronic kidney disease in human. Biosensors and Bioelectronics. 2018;105(January):90-4. 
[31] Lin H, Li L, Lei C, Xu X, Nie Z, Guo M, et al. Immune-independent and label-free fluorescent assay for Cystatin $\mathrm{C}$ detection based on protein-stabilized Au nanoclusters. Biosensors and Bioelectronics. 2013 Mar 15;41(1):256-61.

[32] Lopes P, Costa-rama E, Beirão I, Nouws HPA, Santos- A, Delerue-matos C. Disposable electrochemical immunosensor for analysis of cystatin $\mathrm{C}$, a CKD biomarker. Talanta. 2019;

[33] Jiang R, Xu C, Zhou X, Wang T, Yao G. Detection of Cystatin C biomarker for clinical measurement of renal disease by developed ELISA diagnostic kits. Journal of Translational Medicine. 2014;12(1):1-8.

[34] Delanaye P, Cavalier E, Morel J, Mehdi M, Maillard N, Claisse G, et al. Detection of decreased glomerular filtration rate in intensive care units: serum cystatin $\mathrm{C}$ versus serum creatinine. BMC Nephrology. 2014;15(1):9.

[35] Chocarro-Ruiz B, Fernández-Gavela A, Herranz S, Lechuga LM. Nanophotonic label-free biosensors for environmental monitoring. Current Opinion in Biotechnology. 2017;45:175-83.

[36] Rodriguez BAG, Trindade EKG, Cabral DGA, Soares ECL, Menezes CEL, Ferreira DCM, et al. Nanomaterials for Advancing the Health Immunosensor. In: Biosensors - Micro and Nanoscale Applications. 2015. p. 347-74.

[37] Ding L, Bond AM, Zhai J, Zhang J. Utilization of nanoparticle labels for signal amplification in ultrasensitive electrochemical affinity biosensors: a review. Anal Chim Acta. $2013 ; 797: 1-12$.

[38] Sharma S, Byrne H, O'Kennedy RJ. Antibodies and antibody-derived analytical biosensors. Essays In Biochemistry. 2016;60(1):9-18.

[39] Wang J. Electrochemical biosensors: Towards point-of-care cancer diagnostics. Biosensors and Bioelectronics. 2006;21(10):1887-92.

[40] Song Y, Luo Y, Zhu C, Li H, Du D, Lin Y. Recent advances in electrochemical biosensors based on graphene two-dimensional nanomaterials. Biosensors and Bioelectronics. 2016;76:195-212.

[41] Huang J, Huang W, Wang T. Catalytic and inhibitory kinetic behavior of horseradish peroxidase on the electrode surface. Sensors (Switzerland). 2012;12(11):14556-69. 
[42] Turner APF. Biosensors: sense and sensibility. Chemical Society reviews. 2013;42(8):3184-96.

[43] Stamplecoskie K, Chen Y-S, Kamat P V. Thiolated gold nanoclusters: A new class of photosensitizers [Internet]. 2015 [cited 2019 Jun 23]. p. 71-2. Available from: https://www.sigmaaldrich.com/technical-documents/articles/materials-science/thiolatedgold-nanoclusters.html

[44] Algar WR, Tavares AJ, Krull UJ. Beyond labels: A review of the application of quantum dots as integrated components of assays, bioprobes, and biosensors utilizing optical transduction. Analytica Chimica Acta. 2010;673(1):1-25.

[45] Puttaswamy SV, Lubarsky G v., Kelsey C, Zhang X, Finlay D, McLaughlin JA, et al. Nanophotonic-Carbohydrate Lab-on-a-Microneedle for Rapid Detection of Human Cystatin C in Finger-Prick Blood. ACS Nano. 2020;14(9):11939-49.

[46] Lesnak M, Jursa D, Miskay M, Riedlova H, Barcova K, Adamek M. The determination of cystatin $\mathrm{C}$ in biological samples via the surface plasmon resonance method. BioTechniques. 2021;70(5):1-8.

[47] Trindade EKG, Silva BVM, Dutra RF. A probeless and label-free electrochemical immunosensor for cystatin $\mathrm{C}$ detection based on ferrocene functionalized-graphene platform. Biosensors and Bioelectronics. 2019 Aug 1;138:111311.

[48] Yang ZH, Zhuo Y, Yuan R, Chai YQ. Highly Effective Protein Converting Strategy for Ultrasensitive Electrochemical Assay of Cystatin C. Analytical Chemistry. 2016;88(10):5189-96.

[49] Zhao M, Bai L, Cheng W, Duan X, Wu H, Ding S. Monolayer rubrene functionalized graphene-based eletrochemiluminscence biosensor for serum cystatin $\mathrm{C}$ detection with immunorecognition- induced 3D DNA machine. Biosensors and Bioelectronic. 2018;

[50] Lopes P, Costa-rama E, Beirão I, Nouws HPA, Santos- A, Delerue-matos C. Disposable electrochemical immunosensor for analysis of cystatin $\mathrm{C}$, a CKD biomarker. Talanta. 2019;

[51] Wang B, Yu X, Yin G, Wang J, Jin Y, Wang T. Developing a novel and simple biosensor for Cystatin $\mathrm{C}$ as a fascinating marker of glomerular filtration rate with DNase I-aided 
recycling amplification strategy. Journal of Pharmaceutical and Biomedical Analysis [Internet]. 2021;203:114230. Available from: https://doi.org/10.1016/j.jpba.2021.114230

[52] Hassanain WA, Izake EL, Ayoko GA. Spectroelectrochemical Nanosensor for the Determination of Cystatin C in Human Blood. Analytical Chemistry. 2018;

[53] Gomes RS, Gomez-Rodríguez BA, Fernandes R, Sales MGF, Moreira FTC, Dutra RF. Plastic antibody of polypyrrole/multiwall carbon nanotubes on screen-printed electrodes for cystatin C detection. Biosensors. 2021;11(6).

[54] Ferreira PAB, Araujo MCM, Prado CM, de Lima RA, Rodríguez BAG, Dutra RF. An ultrasensitive Cystatin $\mathrm{C}$ renal failure immunosensor based on a PPy/CNT electrochemical capacitor grafted on interdigitated electrode. Colloids and Surfaces B: Biointerfaces [Internet]. 2020;189(October 2019):110834. Available from: https://doi.org/10.1016/j.colsurfb.2020.110834 